\title{
Stappia indica sp. nov., isolated from deep seawater of the Indian Ocean
}

\author{
Qiliang Lai, Nan Qiao, Changliang Wu, Fengqin Sun, Jun Yuan \\ and Zongze Shao
}

Correspondence

Zongze Shao

shaozz@163.com
Key Laboratory of Marine Biogenetic Resources, Third Institute of Oceanography, State Oceanic Administration, PR China
In an attempt to investigate polycyclic aromatic hydrocarbon (PAH)-degrading bacteria in deep seawater of the Indian Ocean, many bacterial strains were isolated and characterized taxonomically. This study focused on one of these isolates, designated strain $\mathrm{B}_{106^{\mathrm{T}}}$. Comparative $16 \mathrm{~S}$ rRNA gene sequence analysis indicated that strain $\mathrm{B} 106^{\mathrm{T}}$ belonged to the genus Stappia, in the family Rhodobacteraceae. The genus Stappia was proposed by Uchino et al. (1998) and included Stappia stellulata (formerly Agrobacterium stellulatum ATCC $15215^{\mathrm{T}}=\mathrm{IAM} 12621^{\mathrm{T}}$ ) and Stappia aggregata (formerly Agrobacterium stellulatum ATCC 25650=IAM 12614). More recently, Stappia alba CECT $5095^{\mathrm{T}}$ and Stappia marina mano $18^{\mathrm{T}}$ were reported by Pujalte et al. (2005) and Kim et al. (2006), respectively. Subsequently, Biebl et al. (2007) created the genus Labrenzia to accommodate Labrenzia alexandrii and reclassified S. aggregata, S. alba and S. marina as Labrenzia aggregata, Labrenzia alba and Labrenzia marina, respectively. In addition, Weber \& King (2007) proposed four species, 'Stappia carboxidovorans' M4, 'Stappia conradae'

Abbreviation: $\mathrm{PAH}$, polycyclic aromatic hydrocarbon.

The GenBank/EMBL/DDBJ accession number for the 16S rRNA gene sequence of strain B106 ${ }^{\top}$ is EU726271.

A transmission electron micrograph of cells of strain $B 106^{\top}$ and figures showing polar lipids and rep-PCR comparisons of strain $\mathrm{B} 106^{\top}$ and Stappia stellulata IAM $12621^{\top}$, and a table detailing the cellular fatty acid contents of strain B106 ${ }^{\top}$ and S. stellulata IAM $12621^{\top}$ are available as supplementary material with the online version of this paper.
MIO, 'Stappia kahanamokuae' HI1 and 'Stappia meyerae' GA15, but the names have not been validly published. Accordingly, the aim of the present work was to determine the exact taxonomic position of strain $B 106^{\mathrm{T}}$ by using a polyphasic approach.

Deep seawater was sampled with Niskin bottles attached to a CTD (conductivity, temperature and depth) circular rosette in December 2005 during cruise DY-105A of the research vessel Da-Yang Yi-Hao. The sampling site was at $31.0710^{\circ} \mathrm{S}$ $58.9945^{\circ} \mathrm{E}$ on the southwest Indian Ridge, and was designated as IR-CTD5-6; the depth of the water at the site was $4746 \mathrm{~m}$, and a water sample from a depth of $4196 \mathrm{~m}$ was used for enrichment of PAH-degrading bacteria with $1 \%$ $(\mathrm{v} / \mathrm{v})$ sterilized crude oil and a PAH mixture (final concentrations of 100 p.p.m. phenanthrene, 10 p.p.m. anthracene, 10 p.p.m. fluoranthene and 10 p.p.m. pyrene, dissolved in crude oil) as the carbon and energy source. A later enrichment with the $\mathrm{PAH}$ mixture as the sole carbon and energy source and bacterial isolation on 216L marine agar medium (comprising, per $\mathrm{l}^{-1}$ seawater: $\mathrm{CH}_{3} \mathrm{COONa}$, $1.0 \mathrm{~g}$; tryptone, $10.0 \mathrm{~g}$; yeast extract, $2.0 \mathrm{~g}$; sodium citrate, $0.5 \mathrm{~g} ; \mathrm{NH}_{4} \mathrm{NO}_{3}, 0.2 \mathrm{~g} ; \mathrm{pH} 7.5$ ) were performed using the method described by Lai et al. (2009). For morphological and biochemical characterization, strain $\mathrm{B} 106^{\mathrm{T}}$ was also cultivated on $216 \mathrm{~L}$ medium.

Genomic DNA was prepared according to the method of Ausubel et al. (1995) and the 16S rRNA gene was amplified 
by PCR using primers that have been described previously (Liu \& Shao, 2005). Sequences of related taxa were obtained from the GenBank database. Phylogenetic analysis was performed by using MEGA version 4 (Tamura et al., 2007) after multiple alignment of data by using DNAMAN (version 5.1; Lynnon Biosoft). Distances (distance options according to the Kimura two-parameter model) and clustering with the neighbour-joining method of Saitou \& Nei (1987) and minimum-evolution methods of Rzhetsky \& Nei (1992, 1993) were determined by using bootstrap values based on 1000 replications. Clustering results using the minimum-evolution approach were similar to those obtained using neighbour-joining (data not shown).

An almost full-length $16 \mathrm{~S}$ rRNA gene sequence (1448 nt) of strain $\mathrm{B}_{106^{\mathrm{T}}}$ was determined. As shown in Fig. 1, the phylogenetic tree based on 16S rRNA gene sequences showed that strain $B 106^{\mathrm{T}}$ and S. stellulata IAM $12621^{\mathrm{T}}$ formed an independent monophyletic cluster, with a high bootstrap value $(100 \%)$. The two strains shared a $16 \mathrm{~S}$ rRNA gene sequence similarity of $97.7 \%$. The sequences of type strains of other species had $<95.4 \%$ similarity to strain $\mathrm{B} 106^{\mathrm{T}}$. This high similarity strongly confirmed that strain $\mathrm{B}_{106}{ }^{\mathrm{T}}$ belonged to the genus Stappia. In addition, the phylogenetic comparisons performed in this study demonstrated that 'Stappia carboxidovorans' M4, 'Stappia conradae' MIO, 'Stappia kahanamokuae' HI1 and 'Stappia meyerae' GA15 were more closely related to the genera Labrenzia and Pannonibacter (Fig. 1). Further studies are needed to determine their exact taxonomic positions.

DNA-DNA hybridization experiments were performed with genomic DNA from strain $\mathrm{B} 106^{\mathrm{T}}$ and S. stellulata IAM $12621^{\mathrm{T}}$ using a method described by Liu \& Shao (2005). Genomic DNA from Escherichia coli DH5 $\alpha$ was used as an

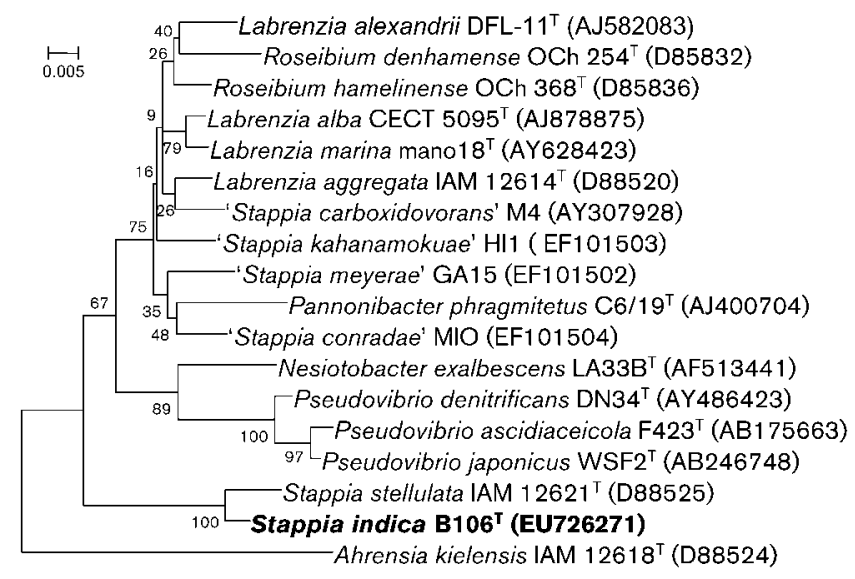

Fig. 1. Neighbour-joining tree showing the phylogenetic positions of strain $B 106^{\top}$ and representatives of some other related taxa, based on 16S rRNA gene sequences. Bootstrap values (expressed as percentages of 1000 replications) are shown at branch points. Bar, 0.005 nucleotide substitution rate $\left(K_{\text {nuc }}\right)$ units. outgroup sample. Salmon sperm DNA was used as a negative control. The results showed that strain $\mathrm{B} 106^{\mathrm{T}}$ and S. stellulata IAM $12621^{\mathrm{T}}$ had a low DNA-DNA relatedness $(43 \%)$, demonstrating their affiliation to separate species in accordance with the cut-off value of $70 \%$ recognized by Wayne et al. (1987) for the discrimination of bacterial species. Strain $\mathrm{B} 106^{\mathrm{T}}$ and S. stellulata IAM $12621^{\mathrm{T}}$ were further compared by using rep-PCR. In this study, the primer BOX-A1R (5'-CTACGGCAAGGCGACGCTGACG-3') was used for rep-PCR fingerprint analysis (Versalovic et al., 1991). PCR was carried out with the following cycle conditions: denaturation for $5 \mathrm{~min}$ at $94{ }^{\circ} \mathrm{C} ; 35$ cycles of $15 \mathrm{~s}$ at $94{ }^{\circ} \mathrm{C}, 30 \mathrm{~s}$ at $53{ }^{\circ} \mathrm{C}$ and $8 \mathrm{~min}$ at $65{ }^{\circ} \mathrm{C}$ and a final extension at $65{ }^{\circ} \mathrm{C}$ for $8 \mathrm{~min}$. The PCR products were separated by using agarose $(2 \%)$ gel electrophoresis. The rep-PCR results are shown in Supplementary Fig. S1 (in IJSEM Online). Strain B106 showed a unique pattern rep-PCR fingerprint in comparison with S. stellulata IAM $12621^{\mathrm{T}}$. These results confirmed the results of the DNA-DNA hybridization.

Gram reaction, catalase, oxidase and lipase (Tween 80) activities, hydrolysis of aesculin and starch, optimal growth temperature and $\mathrm{pH}$, tolerance to $\mathrm{NaCl}$, antibiotic susceptibility, general cell morphology and electron microscopy were studied as described previously (Lai et al., 2009). Other biochemical tests were carried out using API 20NE and API ZYM strips (bioMérieux) and the Biolog GN2 MicroPlate test panel according to the manufacturers' instructions, except that the $\mathrm{NaCl}$ concentration was adjusted in all tests to $3.0 \%$. S. stellulata IAM $12621^{\mathrm{T}}$ was tested at the same time as strain $\mathrm{B} 106^{\mathrm{T}}$ for comparison. The results are given in the species description and Table 1.

The major respiratory quinone of strain $\mathrm{B} 106^{\mathrm{T}}$ was determined to be ubiquinone $10(\mathrm{Q} 10)$ by using HPLC analysis according to Collins (1985). This trait is in accordance with the properties of S. stellulata IAM $12621^{\mathrm{T}}$. Fatty acids in whole cells grown on $216 \mathrm{~L}$ medium at $28{ }^{\circ} \mathrm{C}$ for $48 \mathrm{~h}$ were extracted, saponified and esterified, followed by GC analysis of the fatty acid methyl esters according to the instructions of the MIDI system (Sasser, 1997). The fatty acid profile of S. stellulata IAM $12621^{\mathrm{T}}$ was determined in parallel with strain $\mathrm{B} 106^{\mathrm{T}}$ in this study. The results of both strains are shown in Supplementary Table S1 in IJSEM Online. The major fatty acids in both strains were $\mathrm{C}_{18: 1} \omega 7 c$ and $\mathrm{C}_{18: 1} \omega 7 c$ 11-methyl, which accounted for $>77 \%$ of the total fatty acids. The fatty acid profile of S. stellulata IAM $12621^{\mathrm{T}}$ was similar to that determined by Kim et al. (2006). The two strains differed greatly $(>7 \%)$ in the content of $\mathrm{C}_{18: 1} \omega 7 c$ 11-methyl. As the fatty acid profiles of strain $\mathrm{B} 106^{\mathrm{T}}$ and S. stellulata IAM $12621^{\mathrm{T}}$ were determined under the same conditions, this difference in proportion could be used to distinguish strain $\mathrm{B}_{106}{ }^{\mathrm{T}}$ from S. stellulata IAM $12621^{\mathrm{T}}$.

Polar lipids of strain $\mathrm{B} 106^{\mathrm{T}}$ and S. stellulata IAM $12621^{\mathrm{T}}$ were extracted and separated according to the methods 
Table 1. Physiological characteristics that differentiate strain $B 106^{\top}$ and Stappia stellulata IAM $12621^{\top}$

Strains: $1, \mathrm{~B} 106^{\mathrm{T}}$ (Stappia indica sp. nov.); 2, S. stellulata IAM $12621^{\mathrm{T}}$. W, Weak; +, positive; -, negative.

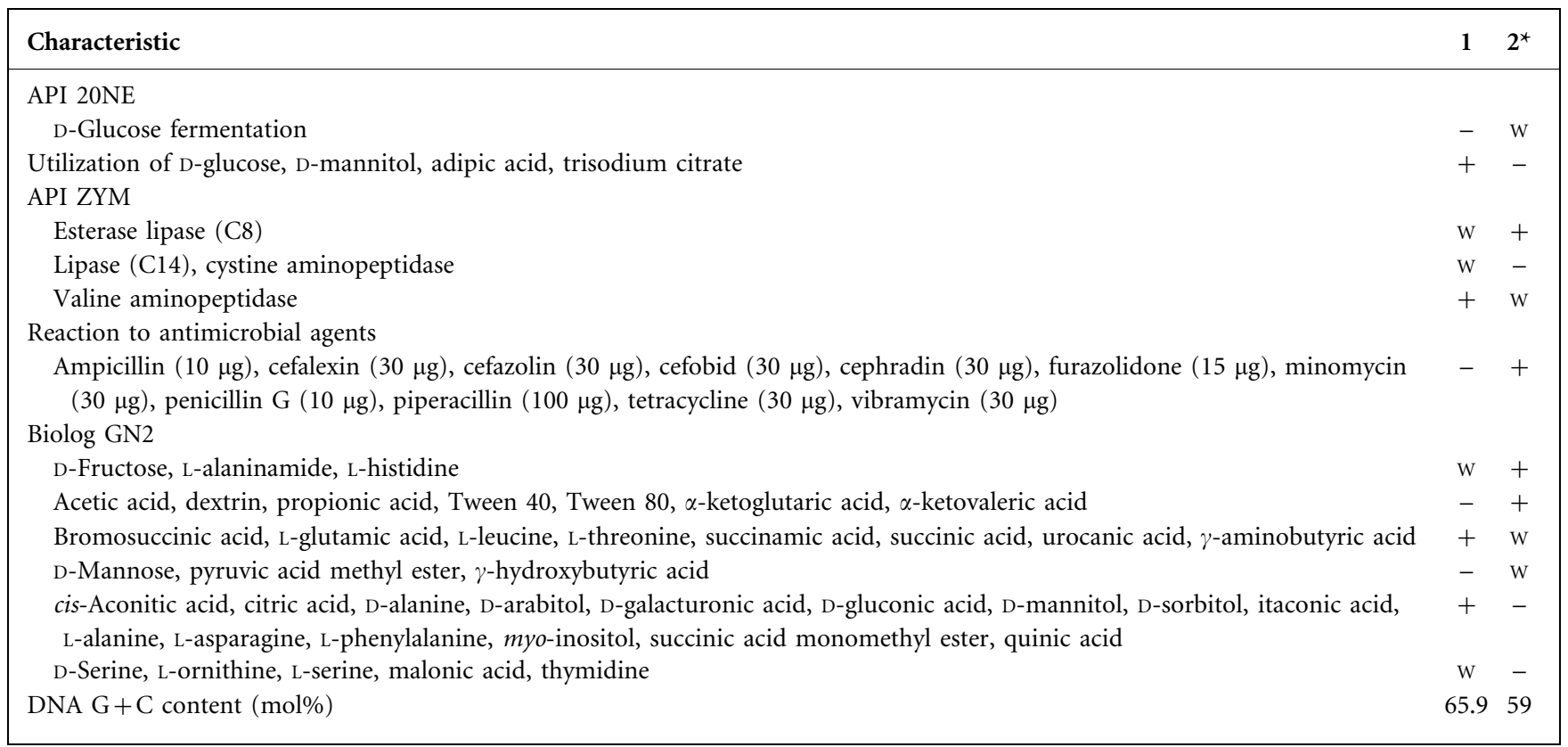

${ }^{\star}$ The characteristics of strain IAM $12621^{\mathrm{T}}$ were analysed at the same time as those of strain $\mathrm{B} 106^{\mathrm{T}}$. Other characteristics tested by using API $20 \mathrm{NE}$, API ZYM and Biolog and susceptibility to antibiotics not listed were the same as those of strain $\mathrm{B}_{106^{\mathrm{T}}}$.

described by Tindall (1990). The results are shown in Supplementary Fig. S2 in IJSEM Online. The major polar lipids of strain B106 ${ }^{\mathrm{T}}$ and S. stellulata IAM $12621^{\mathrm{T}}$ were an unidentified aminolipid, diphosphatidylglycerol, phosphatidylglycerol, phosphatidylcholine and phosphatidylethanolamine. Some unidentified lipids were detected in both strains. These results were similar to those of Biebl et al. (2007).

Antibiotic susceptibility tests were performed by using disc diffusion methods as described by Shieh et al. (2003). Strain B106 ${ }^{\mathrm{T}}$ and S. stellulata IAM $12621^{\mathrm{T}}$ were tested at the same time in this study. Both strains were sensitive to carbenicillin (100 $\mu \mathrm{g}$ per disc; Oxoid), chloromycetin $(30 \mu \mathrm{g})$, ciprofloxacin $(5 \mu \mathrm{g})$, co-trimoxazole $(25 \mu \mathrm{g})$, erythromycin $(15 \mu \mathrm{g})$, gentamicin $(10 \mu \mathrm{g})$, kanamycin $(30 \mu \mathrm{g})$, neomycin $(10 \mu \mathrm{g})$, norfloxacin $(10 \mu \mathrm{g})$, ofloxacin $(5 \mu \mathrm{g})$ and rifampicin $(5 \mu \mathrm{g})$; resistant to clindamycin $(2 \mu \mathrm{g})$, lincomycin $(2 \mu \mathrm{g})$, metronidazole $(5 \mu \mathrm{g})$, oxacillin $(1 \mu \mathrm{g})$, polymyxin $\mathrm{B}$ (30 IU), rocephin $(30 \mu \mathrm{g})$, streptomycin $(10 \mu \mathrm{g})$ or vancomycin $(30 \mu \mathrm{g})$. The susceptibility patterns to antibiotics of the two strains studied are shown in Table 1.

The $\mathrm{G}+\mathrm{C}$ content of the chromosomal DNA was determined according to the method described by Mesbah \& Whitman (1989) using reversed-phase HPLC. The DNA $\mathrm{G}+\mathrm{C}$ content of strain $\mathrm{B} 106^{\mathrm{T}}$ was $65.9 \mathrm{~mol} \%$, which is higher than that of S. stellulata IAM $12621^{\mathrm{T}}(59 \mathrm{~mol} \%)$.

Strain $\mathrm{B}_{106^{\mathrm{T}}}$ was a Gram-negative, non-pigmented, rodshaped bacterium that was motile by means of a polar flagellum (see Supplementary Fig S3, in IJSEM Online).
The differences in physiological, biochemical and chemotaxonomic characteristics between strain $\mathrm{B}_{106^{\mathrm{T}}}$ and $S$. stellulata IAM $12621^{\mathrm{T}}$ are given in Table 1 . The high $16 \mathrm{~S}$ rRNA gene similarity between strain $\mathrm{B} 106^{\mathrm{T}}$ and S. stellulata IAM $12621^{\mathrm{T}}$ indicated strongly that strain $\mathrm{B} 106^{\mathrm{T}}$ belonged to the genus Stappia. However, strain $\mathrm{B} 106^{\mathrm{T}}$ could be differentiated from S. stellulata IAM $12621^{\mathrm{T}}$ based on physiological and chemotaxonomic characteristics, DNADNA hybridization and rep-PCR fingerprint comparison. On the basis of the data described above, strain $\mathrm{B}_{106^{\mathrm{T}}}$ represents a novel species of the genus Stappia, for which the name Stappia indica sp. nov. is proposed.

\section{Description of Stappia indica sp. nov.}

Stappia indica (in.di'ca. L. fem. adj. indica Indian, referring to the Indian Ocean, where the strain was isolated).

Cells are rod-shaped, about $1.0 \mu \mathrm{m}$ wide and $1.0 \mu \mathrm{m}$ long, and motile by means of a single polar flagellum. Positive for oxidase and catalase, but negative for the Gram reaction, indole production, starch hydrolysis, gelatinase, $\beta$-glucosidase, $\beta$-galactosidase, urease and arginine dihydrolase. On $216 \mathrm{~L}$ agar plates, forms smooth grey-white colonies with regular edges, $2-3 \mathrm{~mm}$ in diameter after $72 \mathrm{~h}$ incubation at $28{ }^{\circ} \mathrm{C}$, non-pigmented and slightly raised in the centre. Moderately halophilic, grows in $0.5-11 \% \mathrm{NaCl}$ (optimum, 1-5\%) and at 4-42 ${ }^{\circ} \mathrm{C}$ (optimum, 25-37 ${ }^{\circ} \mathrm{C}$ ), but not at $45{ }^{\circ} \mathrm{C}$. Reduces nitrate, but does not ferment glucose. Major fatty acids are $\mathrm{C}_{16: 0}, \mathrm{C}_{18: 1} \omega 7 c, \mathrm{C}_{18: 0}$, 
$\mathrm{C}_{18: 1} \omega 7 c$ 11-methyl and $\mathrm{C}_{19: 0} \omega 8 c$ cyclo. Sensitive to (per disc; Oxoid): carbenicillin $(100 \mu \mathrm{g})$, chloromycetin $(30 \mu \mathrm{g})$, ciprofloxacin $(5 \mu \mathrm{g})$, co-trimoxazole $(25 \mu \mathrm{g})$, erythromycin $(15 \mu \mathrm{g})$, gentamicin $(10 \mu \mathrm{g})$, kanamycin $(30 \mu \mathrm{g})$, neomycin $(10 \mu \mathrm{g})$, norfloxacin $(10 \mu \mathrm{g})$, ofloxacin $(5 \mu \mathrm{g})$ and rifampicin $(5 \mu \mathrm{g})$; resistant to ampicillin $(10 \mu \mathrm{g})$, cefalexin $(30 \mu \mathrm{g})$, cefazolin $(30 \mu \mathrm{g})$, cefobid $(30 \mu \mathrm{g})$, cephradin $(30 \mu \mathrm{g})$, clindamycin $(2 \mu \mathrm{g})$, furazolidone $(15 \mu \mathrm{g})$, lincomycin $(2 \mu \mathrm{g})$, metronidazole $(5 \mu \mathrm{g})$, minomycin $(30 \mu \mathrm{g})$, oxacillin $(1 \mu \mathrm{g})$, penicillin $\mathrm{G}(10 \mu \mathrm{g})$, piperacillin $(100 \mu \mathrm{g})$, polymyxin B (30 IU), rocephin $(30 \mu \mathrm{g})$, streptomycin $(10 \mu \mathrm{g})$, tetracycline $(30 \mu \mathrm{g})$, vancomycin $(30 \mu \mathrm{g})$ and vibramycin $(30 \mu \mathrm{g})$. In API ZYM tests, positive for acid phosphatase, alkaline phosphatase, esterase (C4), leucine aminopeptidase, trypsin and valine aminopeptidases; weakly positive for cystine aminopeptidase, esterase lipase (C8), lipase (C14) and naphthol-AS-Bl-phosphoamidase; and negative for $\mathrm{N}$ acetyl- $\beta$-glucosaminidase, $\alpha$-chymotrypsin, $\alpha$-fucosidase, $\alpha$-galactosidase, $\alpha$-glucosidase, $\alpha$-mannosidase, $\beta$-galactosidase, $\beta$-glucosidase and $\beta$-glucuronidase. Of 95 substrates in the Biolog GN2 system, positive for bromosuccinic acid, cis-aconitic acid, citric acid, DL-lactic acid, D-alanine, Darabitol, D-galacturonic acid, D-gluconic acid, D-mannitol, D-sorbitol, glycerol, glycyl L-glutamic acid, itaconic acid, L-alanine, L-alanyl glycine, L-asparagine, L-glutamic acid, Lleucine, L-phenylalanine, L-proline, L-threonine, myoinositol, succinic acid monomethyl ester, quinic acid, succinamic acid, succinic acid, urocanic acid, $\alpha$-D-glucose, $\alpha$-hydroxybutyric acid, $\alpha$-ketobutyric acid, $\beta$-hydroxybutyric acid and $\gamma$-aminobutyric acid; weakly positive for Dfructose, D-serine, glycogen, glycyl L-aspartic acid, hydroxy-L-proline, L-alaninamide, L-histidine, L-ornithine, $\mathrm{L}$-serine, malonic acid and thymidine. The $\mathrm{G}+\mathrm{C}$ content of the DNA of the type strain is $65.9 \mathrm{~mol} \%$.

The type strain, $\quad \mathrm{B}^{106^{\mathrm{T}}} \quad\left(=\mathrm{PR} 56-8^{\mathrm{T}}=\mathrm{CCTCC} \quad \mathrm{AB}\right.$ $208228^{\mathrm{T}}=$ LMG $24625^{\mathrm{T}}=$ MCCC $\left.1 \mathrm{~A} 01226^{\mathrm{T}}\right)$, was isolated from deep seawater of the Indian Ocean.

\section{Acknowledgements}

This work was supported financially by the National Infrastructure of Natural Resources for Science and Technology Program of China (no. 2005DKA21209), the COMRA program (no. DYXM-115-02-2-05) and the National Natural Science Foundation of China (no. 30670051).

\section{References}

Ausubel, F. M., Brent, R., Kingston, R. E., Moore, D. D., Seidman, J. G., Smith, J. A. \& Struhl, K. (editors) (1995). Short Protocols in Molecular Biology: a Compendium of Methods from Current Protocols in Molecular Biology, 3rd edn. New York: Wiley.

Biebl, H., Pukall, R., Lünsdorf, H., Schulz, S., Allgaier, M., Tindall, B. J. \& Wagner-Döbler, I. (2007). Description of Labrenzia alexandrii gen. nov., sp. nov., a novel alphaproteobacterium containing bacteriochlorophyll $a$, and a proposal for reclassification of Stappia aggregata as Labrenzia aggregata comb. nov., of Stappia marina as Labrenzia marina comb. nov. and of Stappia alba as Labrenzia alba comb. nov., and emended descriptions of the genera Pannonibacter, Stappia and Roseibium, and of the species Roseibium denhamense and Roseibium hamelinense. Int J Syst Evol Microbiol 57, 1095-1107.

Collins, M. D. (1985). Isoprenoid quinone analysis in bacterial classification and identification. In Chemical Methods in Bacterial Systematics, pp. 267-287. Edited by M. Goodfellow \& D. E. Minnikin. London: Academic Press.

Kim, B.-C., Park, J. R., Bae, J.-W., Rhee, S.-K., Kim, K. H., Oh, J.-W. \& Park, Y.-H. (2006). Stappia marina sp. nov., a marine bacterium isolated from the Yellow Sea. Int J Syst Evol Microbiol 56, 75-79.

Lai, Q., Yuan, J., Wu, C. \& Shao, Z. (2009). Oceanibaculum indicum gen. nov., sp. nov., isolated from deep seawater of the Indian Ocean. Int J Syst Evol Microbiol 59, 1733-1737.

Liu, C. \& Shao, Z. (2005). Alcanivorax dieselolei sp. nov., a novel alkane-degrading bacterium isolated from sea water and deep-sea sediment. Int J Syst Evol Microbiol 55, 1181-1186.

Mesbah, M. \& Whitman, W. B. (1989). Measurement of deoxyguanosine/thymidine ratios in complex mixtures by high-performance liquid chromatography for determination of the mole percentage guanine + cytosine of DNA. J Chromatogr A 479, 297-306.

Pujalte, M. J., Macian, M. C., Arahal, D. R. \& Garay, E. (2005). Stappia alba sp. nov., isolated from Mediterranean oysters. Syst Appl Microbiol 28, 672-678.

Rzhetsky, A. \& Nei, M. (1992). A simple method for estimating and testing minimum evolution trees. Mol Biol Evol 9, 945-967.

Rzhetsky, A. \& Nei, M. (1993). Theoretical foundation of the minimum-evolution method of phylogenetic inference. Mol Biol Evol 10, 1073-1095.

Saitou, N. \& Nei, M. (1987). The neighbor-joining method: a new method for reconstructing phylogenetic trees. Mol Biol Evol 4, 406425.

Sasser, M. (1997). Identification of bacteria by gas chromatography of cellular fatty acids. MIDI Technical Note 101. Newark, DE: MIDI.

Shieh, W. Y., Chen, Y.-W., Chaw, S.-M. \& Chiu, H.-H. (2003). Vibrio ruber sp. nov., a red, facultatively anaerobic, marine bacterium isolated from sea water. Int J Syst Evol Microbiol 53, 479-484.

Tamura, K., Dudley, J., Nei, M. \& Kumar, S. (2007). MEGA4: Molecular Evolutionary Genetics Analysis (MEGA) software version 4.0. Mol Biol Evol 24, 1596-1599.

Tindall, B. J. (1990). Lipid composition of Halobacterium lacusprofundi. FEMS Microbiol Lett 66, 199-202.

Uchino, Y., Hirata, A., Yakota, A. \& Sugiyama, J. (1998). Reclassification of marine Agrobacterium species: proposals of Stappia stellulata gen. nov., comb. nov., Stappia aggregata sp. nov., nom. rev., Ruegeria atlantica gen. nov., comb. nov., Ruegeria gelatinovora comb. nov., Ruegeria algicola comb. nov., and Ahrensia kieliense gen. nov., sp. nov., nom. rev. J Gen Appl Microbiol 44, 201210.

Versalovic, J., Koeuth, T. \& Lupski, J. R. (1991). Distribution of repetitive DNA sequences in eubacteria and application to fingerprinting of bacterial genomes. Nucleic Acids Res 19, 6823-6831.

Wayne, L. G., Brenner, D. J., Colwell, R. R., Grimont, P. A. D., Kandler, O., Krichevsky, M. I., Moore, L. H., Moore, W. E. C., Murray, R. G. E. \& other authors (1987). Report of the ad hoc committee on reconciliation of approaches to bacterial systematics. Int J Syst Bacteriol 37, 463-464.

Weber, C. F. \& King, G. M. (2007). Physiological, ecological, and phylogenetic characterization of Stappia, a marine CO-oxidizing bacterial genus. Appl Environ Microbiol 73, 1266-1276. 